\title{
Unemployment, poverty, and hunger in Brazil in Covid-19 pandemic times
}

\author{
Desemprego, pobreza e fome no Brasil \\ em tempos de pandemia por Covid-19
}

\section{A B S T R A C T}

This scientific note presents preliminary developments of the Covid-19 pandemic on unemployment, poverty, and hunger in Brazil. The data on unemployment rate, un employment insurance claims, contingent of families in extreme poverty, and food insecurity was collected in government information systems, research published by public agencies, scientific articles, and in news portals. In an upward trajectory since 2015, the increase in unemployment and the number of families in extreme poverty was exacerbated after the pandemic began, drastically reducing the purchase power and access to healthy and adequate food, affecting mainly women and the populations of the Northern and Northeastern regions. Between January and September 2020, there was a 3\% increase in unemployment in Brazil and, in October 2020, there were almost 485 thousand more families in extreme poverty compared to January of the same year. There are inadequate and insufficient responses from the Brazilian government to the articulated set of problems. The Covid-19 pandemic is a new element that potentiates the recent increase in hunger in Brazil, which occurs in parallel with the dismantling of the Food and Nutrition Security programs and the expansion of fiscal austerity measures, started with the political-economic crisis in 2015. There is an urgent need to recover the centrality of the agenda to fight hunger in Brazil, associated with the development of more robust contributions on the impact of the pandemic on the phenomena of poverty and hunger.

Keywords: Coronavirus infections. Food and nutrition security. Hunger. Poverty. Social vulnerability. Unemployment.

\footnotetext{
${ }^{1}$ Universidade Federal de São Paulo, Instituto de Saúde e Sociedade, Programa de Pós-Graduação Interdisciplinar em Ciências da Saúde. Santos, SP, Brasil.

2 Universidade Federal de Santa Catarina, Centro de Ciências da Saúde, Programa de Pós-Graduação em Nutrição. R. Engenheiro Agronômico Andrei Cristian Ferreira, s/n., Trindade, 88040-900, Florianópolis, SC, Brasil. Correspondence to: FAG VASCONCELOS. E-mail: <f.vasconcelos@ufsc.br>.
}

How to cite this article

Neves JA, Machado ML, Oliveira LDA, Moreno YMF, Medeiros MAT, Vasconcelos FAG. Unemployment, poverty, and hunger in Brazil in Covid-19 pandemic times. Rev Nutr. 2021;34:e200170. https://doi.org/10.1590/1678-9865202134e200170 


\section{RE S U M O}

Nesta nota científica apresentam-se desdobramentos preliminares da pandemia de Covid-19 sobre o desemprego, a pobreza e a fome no Brasil. Utilizaram-se dados sobre a taxa de desocupação, solicitações de seguro-desemprego e contingente de familias em extrema pobreza e em insegurança alimentar, coletados em sistemas de informação governamentais, em pesquisas publicadas por órgãos públicos, em artigos científicos e em portais de notícias. Em trajetória ascendente, desde 2015, identificou-se um aumento do desemprego e do número de famílias em extrema pobreza após a instauração da pandemia, o que pode reduzir drasticamente o poder de compra e o acesso à alimentação adequada e saudável, afetando, principalmente, as mulheres e a população das regiões Norte e Nordeste. Entre janeiro e setembro de 2020, houve o aumento de 3\% desemprego no Brasil e, em outubro de 2020, havia quase 485 mil familias a mais em situação de extrema pobreza, relativamente a janeiro do mesmo ano. Verificam-se respostas inadequadas e insuficientes do governo brasileiro frente ao conjunto articulado de problemas. A pandemia de Covid-19 consiste em um novo elemento potencializador do aumento recente da fome no Brasil, que ocorre paralelamente ao desmonte dos programas de Segurança Alimentar e Nutricional e à ampliação de medidas de austeridade fiscal iniciadas com a crise político-econômica em 2015. Urge resgatar a centralidade da agenda de combate à fome no Brasil, associadamente ao desenvolvimento de contribuições mais robustas sobre o impacto da pandemia nos fenômenos da pobreza e da fome.

Palavras-chave: Infecção por coronavírus. Segurança Alimentar e Nutricional. Fome. Pobreza. Vulnerabilidade social. Desemprego.

The Coronavirus 19 (Covid-19) pandemic was declared by the World Health Organization (WHO) on March 11, 2020. Nine days later, the state of community transmission of the virus was also declared in Brazil; up to December 17, 2020, there had been 7,110,434 cases and 184,827 deaths in the country making it the third largest total numberof cases in the world andthe second in the number of deaths $[1,2]$. Also, while there were 3,426 cases per 100,000 inhabitants in the Northern and Northeastern regions of the country, the average was 3,319 cases per 100.000 inhabitantsin the other regions [2].

According to the $\mathrm{WHO}$, social isolation is the best strategy for containing the transmission of the disease, for which there is currently no specific pharmacological treatment $[3,4]$. Consequently, economic activities have been paralyzed or reduced in Brazil, resulting in growing unemployment, poverty, and hunger and requiring acts of government to mitigate the worsening health and socioeconomic conditions of the population $[5,6]$.

In this scientific note, we aim to discuss the consequences of the Covid-19 pandemic in preliminary indexes of unemployment, poverty, and hunger, as well as to evaluate governmental action in that scenario. To look into unemployment, we will use data from the Instituto Brasileiro de Geografia e Estatística (IBGE, Brazilian Institute of Geography and Statistics) and from the Instituto de Pesquisa Econômica Aplicada (IPEA, Brazilian Institute of Applied Economic Research), as well as the number of people who required unemployment insurance from the government, provided by the Brazilian Ministry of Economy. To describe poverty, we evaluated the Ministry of Citizenship's database on social information to check for the number of families in extreme poverty. The data on food insecurity, which indicated hunger, was also provided by IBGE. As a complement, we have analyzed scientific articles and reports published by news agencies, which provide updated data on the variables of interest in the research.

Since 2015, unemployment has been rising among the Brazilian population aged 14 or older, and it has escalated after the beginning of the pandemic and measures related to its containment [7] (Figure 1). We understand as unemployed the out-of-work population who is currently seeking occupation [8]. In the third trimester of 2020, there were 13.7 million people out of work (14.6\% of the 14-or-older population), with an increase of 3 million people by January 2021 [7]. Despite the general national growth, there are also regional and gender disparities to be observed: unemployment is larger among women (16.8\%) and in the Northeastern region (17.9\%) of the country [7]. IPEA has also identified growing unemployment, striking 
$13.7 \%$ of the population in July 2020 and justified by the retraction of activities in the labor market due to the pandemic [9]. Data of the Ministry of Economy showthat in the first five months of 2020, Brazil has accumulated 3,297,396 requests for unemployment insurance, representing an increase of $12.4 \%$ of the total in 2019 [10]. In May 2020, such percentage has increased by $28.3 \%$ compared to the previous month and 53\% compared to the same month in 2019 [10].

The increase in the unemployment rates was accompanied by the growth of the number of families in extreme poverty (monthly income of up to $\mathrm{R} \$ 89.00$ per person), which was equally enlarged in October 2020 (Figure 2), reaching about 20\% of the Brazilian families [11,12].

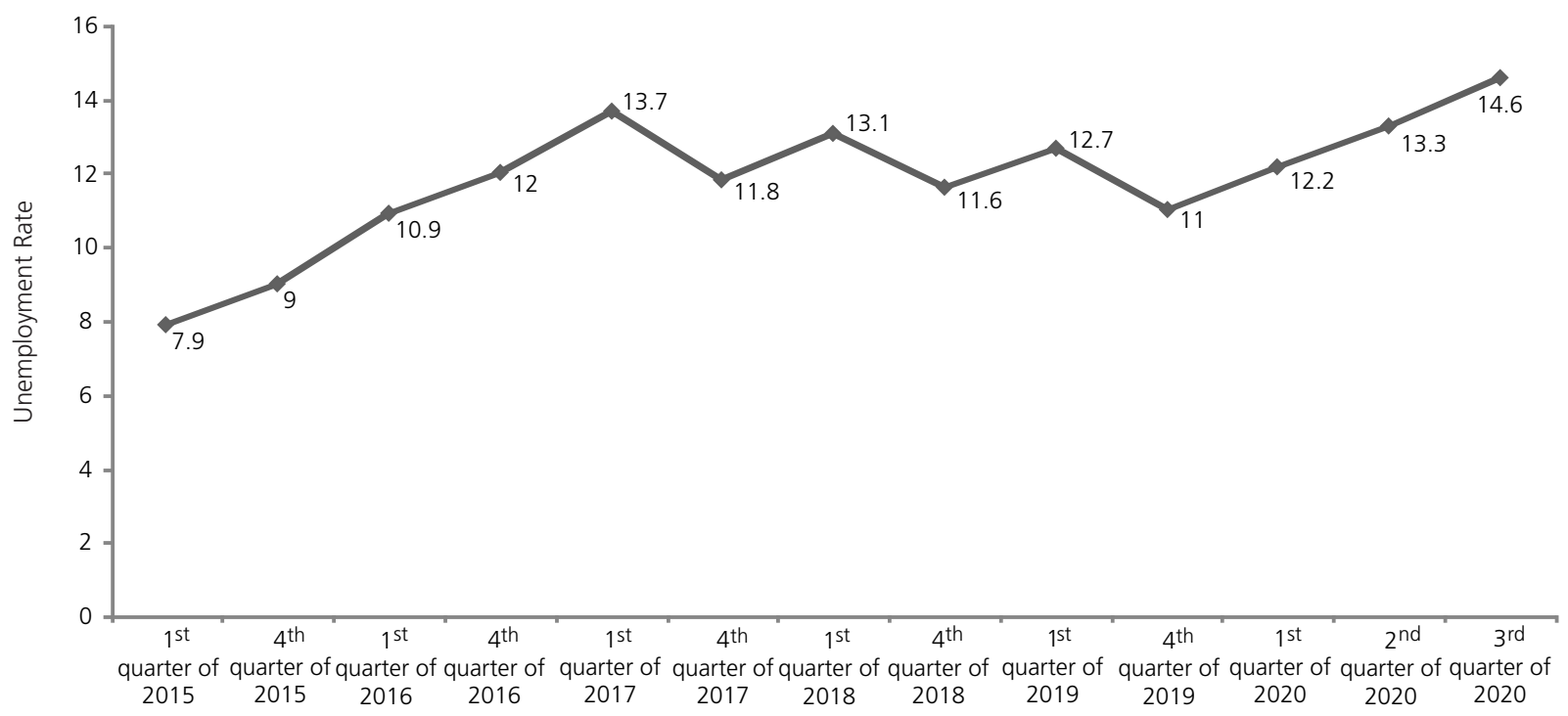

Figure 1 - Unemployment rate (\%) of the Brazilian population aged 14 or older between 2015 and the third trimester of 2020. Brazil, 2020.

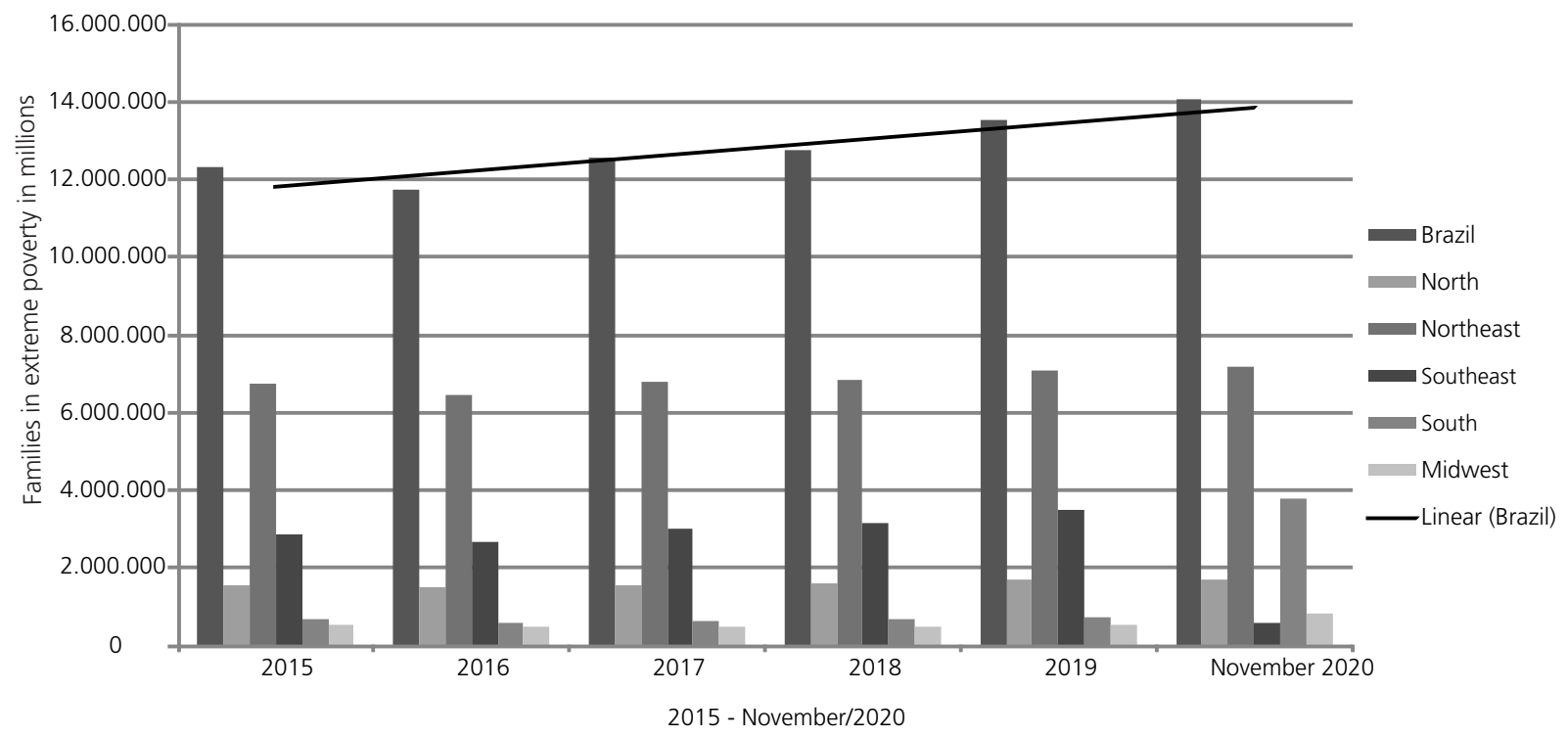

Figure 2 - Families in extreme poverty between 2015 and October 2020. Brazil, 2020. 
Family income is one of the factors associated with Food Insecurity (FI) and the increase in unemployment and extreme poverty might drastically reduce people's purchase power and access to adequate and healthy food [13-15]. In Brazil, FI is measured by the Escala Brasileira de Insegurança Alimentar (EBIA, Brazilian Food Insecurity Scale), which expresses the families' perceptions regarding access to food [16]. International records indicate that the pandemic might increase $\mathrm{Fl}$, especially in countries like Brazil, with previous challenges in reducingpovertyand hunger $[17,18]$. Thirteen of the seventeen Brazilian capitals investigated by the National Research on Basic Foods applied by the Departamento Intersindical de Estatísticas e Estudos Socioeconômicos (DIEESE, Interunion Department of Socioeconomic Statistics and Studies) demonstrated a rise in the prices of natural and minimallyprocessed foods. In the state of São Paulo, for instance, these prices accumulated a 12\% rise in the last 12 months, a situation that is further aggravated by the restrictions in circulation, which limit the available labor force, but mostly by protectionist policies of exportations and importations, that also contribute to rising prices of food items $[19,20]$.

Threatens of shortages alarmed since the beginning of the pandemic persist and worsen the problem of accessing food items, especially for socially vulnerable families, currently one of the largest problems we face due to the Covid-19 pandemic $[19,21,22]$. In that context, it isurgent to recompose the Conselho Nacional de Segurança Alimentar e Nutricional (CONSEA, National Council for Food and Nutrition Security), a fundamental instance in Sistema Nacional de Segurança Alimentar e Nutricional (SISAN, National System of Food and Nutritional Security), and increase coverage of public policies and programs of access to income and food, like the Bolsa Familia Program (PBF), the Programa Nacional de Alimentação Escolar (PNAE, National School Food Program), and public equipment related to food and nutritional security (SAN), associated with public finances for initiatives in the civil society in such area. Stimulating the local production and distribution of food by family farming is strategic to contain the escalation of famine [5,23-25].

In April 2020, the federal government sanctioned the concession of an Emergency Basic Income of $\mathrm{R} \$ 600$ for vulnerable groups during the pandemic [26]. However, the late response, the difficulty in accessing the program, and its temporary character might reduce its effectiveness to the right to food [27]. Moreover, 158,452 people were cut from Bolsa Familia in March 2020, with disproportionate effects in the Northeastern region, that currently holds $25 \%$ of the cases and deaths by Covid-19 in the country, deals witha $17.9 \%$ regional unemployment rate, holds $51 \%$ of the families in extreme poverty in Brazil, and $49.7 \%$ of the families in PBF (Chart 1) [28]. Also, cuts in PBF tend to disproportionately affect women, the program's main beneficiaries. Along with their larger rates of unemployment (Chart 1), such cuts aggravate women's vulnerability to Fl during the pandemic [29].

Chart 1 - Cumulative number of cases and death by Covid-19, unemployed population, families in extreme poverty, and families covered by the Bolsa Familia Program, by Brazilian regions. Brazil, 2020.

\begin{tabular}{|c|c|c|c|c|c|c|c|c|c|c|c|c|}
\hline \multirow[t]{2}{*}{$\begin{array}{l}\text { Brazilian } \\
\text { Regions }\end{array}$} & \multicolumn{2}{|c|}{$\begin{array}{c}\text { Cumulative cases } \\
\text { of Covid-19 }\end{array}$} & \multicolumn{2}{|c|}{$\begin{array}{l}\text { Cumulative } \\
\text { deaths by } \\
\text { Covid-19 } 1\end{array}$} & \multirow[t]{2}{*}{$\begin{array}{l}\text { Unemployed } \\
\text { population } \\
\text { (millions) }^{\mathrm{a}}\end{array}$} & \multicolumn{3}{|c|}{ Unemployment rate $(\%)^{2}$} & \multicolumn{2}{|c|}{$\begin{array}{c}\text { Families in extreme } \\
\text { poverty }\end{array}$} & \multicolumn{2}{|c|}{$\begin{array}{c}\text { Families covered by } \\
\text { Bolsa Família }{ }^{3, c}\end{array}$} \\
\hline & $n$ & $\%$ & $\mathrm{n}$ & $\%$ & & Total & Women & Men & $n$ & $\%$ & $n$ & $\%$ \\
\hline North & 642,474 & 13.0 & 15,191 & 10.3 & 1,042 & 13.1 & - & - & $1,716,855$ & 12.2 & $1,796,535$ & 12.6 \\
\hline Northeast & $1,355,526$ & 27.4 & 39,772 & 21.1 & 3,942 & 17.9 & - & - & 7.171.399 & 51.0 & $7,092,999$ & 49.7 \\
\hline Midwest & 615,013 & 12.4 & 13,183 & 9.0 & 1,033 & 12.7 & - & - & 573,889 & 4.1 & 681,243 & 4.8 \\
\hline Southeast & $1,721,384$ & 34.8 & 66,250 & 45.1 & 6,673 & 15.4 & - & - & $3,787,719$ & 26.9 & $3,812,630$ & 26.7 \\
\hline South & 608,347 & 12.3 & 12,429 & 8.5 & 1,403 & 9.4 & - & - & 808,811 & 5.8 & 890,395 & 6.2 \\
\hline Brazil & $4,942,744$ & 100 & 146,8226 & 100 & 14,092 & 14.6 & 16.8 & 12.8 & $14,058,673$ & 100 & $14,273,802$ & 100 \\
\hline
\end{tabular}

Notes: ${ }^{1}$ Fundação Oswaldo Cruz, Brazil, data referring to December 17, 2020, 8.27 p.m. [2]; ${ }^{2}$ Instituto Brasileiro de Geografia e Estatística [7]; ${ }^{3}$ Ministry of Citizen ship [11]; a Unemployed population: people out-of-work in the week of reference, but who sought work or acted on that sense in a 30-day reference period (data referring to the third trimester of 2020) [8]; ${ }^{\mathbf{b}}$ Data referring to October 2020; ' Data referring to November 2020. 
Although temporary, the Emergency Basic Income has had a positive impact on the most vulnerable population, reaching 30.2 million households. In May 2020, the social policy was the only source of income for $5.2 \%$ of the households (about 3.5 million). It is estimated that the revenue compensated around $45 \%$ of the impact of the pandemic on the total of salaries $[26,30]$.

Concurrently, the federal government debates the creation of a minimum income program, Renda Brasil (Brazil Income), whose beneficiarieswould be the families in PBF, besides informal workers identified with the Basic Emergency Income. However precocious, speculations regarding the supposed program foresee the extinction or reduction of other social policies, like the Benefício de Prestação Continuada (BPC, Continuing Benefit Conveyance), salary bonuses, and unemployment benefits forfisherman during the interdiction season, which are provisions mostly granted for vulnerable populations, like the elderly, disabled persons, and artisanal fishermen. Hence, the debate on a basic income program revives the issues of tax reform and public spending [31,32].

In the areas of food and nutrition, althoughthe country has exitedtheHunger Map in 2014, after over a decade of public policies and programs, according to the United Nations, the economic and political crisis started in 2015 has resulted in institutional ruptures, budget cuts, and drawbacks in social rights and in the agenda of SAN policies [33]. Thus, from 2016 onwards, we have seen the growing prevalence of hunger [34]. On the other hand, new measures of austerity have been debated worldwide, with cuts on social policies [35].

Besides the fragilization of social policies, Brazil also faces the rupture of the processes of dissemination of information regarding Fl. The national data available in August 2020, provided by the Pesquisa Nacional por Amostra de Domicilios (PNAD, National Household Survey), still referred to 2013. In 2017/2018, the Pesquisa de Orçamentos Familiares (POF, Family Budget Research) used EBIA to estimate food insecurity for the first time. According to it, $36.7 \%$ of the investigated households showed some level of food insecurity (against $22.6 \%$ in 2013, according to PNAD): $24 \%$ showed light $\mathrm{Fl}, 8.1 \%$ moderate $\mathrm{Fl}$, and $4.6 \%$ severe $\mathrm{FI}$ [36]. A recent study estimated the increase of food insecurity in Brazil, especiallyamong the population with an income of up to $1 / 4$ of a minimum wage per capita [15], reinforcing the growth of poverty-related hunger [15].

Historically, hunger is measured by indirect indicators that, like EBIA, present limitations in terms of precision [16]. Thus, as concerns about hunger grow in the population, indicators capable of measuringit more precisely, subsidizing decision-making related to its reversion, are more and more important.

The national crisis provoked by Covid-19 exposes the reality of a historical and structurally unequal society in which state action is needed to preserve incomes, jobs, and support vulnerable populations in order to avoid the growth of poverty and hunger [37]. The Brazilian government is recognized both by the UN and the international scientific community as one of the worst in the word when it comes to facing the damages caused by Covid-19 $[38,39]$. Besides the governmental inability to build social and economic policies geared toward results, the pandemic and its effects on unemployment and poverty contribute to the increasing trajectory of hunger in the country.

The number of updated publications on the relations of the pandemic and its socioeconomic outcomes is still reduced, limiting the discussion of the results found in the present study. Given the preliminary character of this note and its use of recently published data on unemployment, poverty, and Fl, we suggest the development of new studies analyzing the impact of the pandemic on the social issues of food insecurity and hunger, and seeking more robust contributions. However, the results presented already point to a rough scenario, in which the relevance of fighting hunger and defending the human right to adequate and healthy food in Brazilian public policies needs to be rescued to reverse the dismantling of the previous years. 


\section{REFERENCES}

1. Ministério da Saúde (Brasil). Portaria $n^{\circ} 454$, de 20 de março de 2020. Declara, em todo o território nacional, o estado de transmissão comunitária do coronavírus (COVID-19). Brasília: Ministério; 2020 [citado 4 jun 2020]. Disponível em: http://www.planalto.gov.br/ccivil_03/portaria/prt454-20-ms.htm

2. Fundação Oswaldo Cruz. MonitoraCOVID-19. Rio de Janeiro: Fundação; 2020 [citado 18 dez 2020]. Disponível em: https://bigdata-covid19.icict.fiocruz.br/

3. Crokidakis N. COVID-19 spreading in Rio de Janeiro, Brazil: do the policies of social isolation really work? Chaos Soliton Fract. 2020;136:e109930. https://doi.org/10.1016/j.chaos.2020.109930

4. Kerr L, Kendall C, Silva AAM, Aquino EML, Pescarini JM, Almeida RLF, et al. COVID-19 no Nordeste brasileiro: sucessos e limitações nas respostas dos governos dos estados. Ciênc Saúde Coletiva. 2020;25(Suppl2):4099-120. https://doi.org/10.1590/1413-812320202510.2.28642020

5. Oliveira TC, Abranches MV, Lana RM. (In)Segurança alimentar no contexto da pandemia por SARS-CoV-2. Cad Saúde Pública. 2020;36(4):e00055220. https://doi.org/10.1590/0102-311×00055220

6. Dickinson M. Food frights: COVID19 and the specter of hunger. Agric Human Values. 2020;[Epub a head of print]. https://doi.org/10.1007\%2Fs10460-020-10063-3

7. Instituto Brasileiro de Geografia e Estatística. Indicadores IBGE: Pesquisa Nacional por Amostra de Domicílios Contínua: terceiro trimestre de 2020. Rio de Janeiro: Instituto; 2020 [citado 18 dez 2020]. Disponível em: https:// biblioteca.ibge.gov.br/visualizacao/periodicos/2421/pnact_2020_3tri.pdf

8. Instituto Brasileiro de Geografia e Estatística. Atlas do Censo Demográfico 2010: glossário. Rio de Janeiro: Instituto; 2010. Disponível em: https://censo2010.ibge.gov.br/apps/atlas/pdf/209_213_Glossario_ATLASDEMO\%202010.pdf

9. Cavalcanti MA, Lameiras MAP. PNAD-COVID: divulgação de 14/08/2020: principais destaques. (Carta de Conjuntura, $n^{\circ}$. 48). Brasília: Instituto de Pesquisa Econômica Aplicada; 2020 [citado 4 out 2020]. Disponível em: https://www. ipea.gov.br/portal/index.php?option=com_alphacontent\&view=alphacontent\&ltemid=369

10. Ministério da Economia (Brasil). Base de Gestão do Seguro-Desemprego. Brasília: Ministério; 2020 [citado 17 jun 2020]. Disponível em: https://ck.govdata.gov.br/dataset/sd-bg

11. Ministério da Cidadania (Brasil). Painel Dados Abertos da Matriz de Informações Sociais. Brasília: Ministério; 2020 [citado 18 dez 2020]. Disponível em: http://aplicacoes.mds.gov.br/sagi-paineis/analise_dados_abertos/

12. Instituto Brasileiro de Geografia e Estatística. Pesquisa de Orçamentos Familiares 2017-2018: primeiros resultados. Rio de Janeiro: Instituto; 2019 [citado 17 jun 2020]. Disponível em: https://biblioteca.ibge.gov.br/visualizacao/livros/ liv101670.pdf

13. Morais DC, Dutra LV, Franceschini SCC, Priore SE. Insegurança alimentar e indicadores antropométricos, dietéticos e sociais em estudos brasileiros: uma revisão sistemática. Ciênc Saúde Coletiva. 2014;19(5):1475-88. https://doi. org/10.1590/1413-81232014195.13012013

14. Bezerra TA, Olinda RA, Pedraza DF. Insegurança alimentar no Brasil segundo diferentes cenários sociodemográficos. Ciênc Saúde Coletiva. 2017;22(2):637-51. https://doi.org/10.1590/1413-81232017222.19952015

15. Sousa LRM, Segall-Corrêa AM, Ville AS, Melgar-Quiñonez H. Food security status in times of financial and political crisis in Brazil. Cad Saúde Pública. 2019;35(7):e00084118. https://doi.org/10.1590/0102-311x00084118

16. Kepple A, Segall-Corrêa AM. Conceituando e medindo segurança alimentar e nutricional. Ciênc Saúde Coletiva. 2011;16(1):187-99. https://doi.org/10.1590/S1413-81232011000100022

17. United Nations Organization. Policy brief: the impact of COVID-19 on Food Security and Nutrition. Geneva: Organization; 2020 [cited 2020 June 11]. Available from: https://www.un.org/sites/un2.un.org/files/sg_policy_brief_ on_covid_impact_on_food_security.pdf

18. Wolfson JA, Leung CW. Food Insecurity and COVID-19: disparities in early effects for US adults. Nutrients. 2020;12(6):1648. https://doi.org/10.3390/nu12061648

19. Silva-Filho OJ, Gomes-Júnior NN. O amanhã vai à mesa: abastecimento alimentar e COVID-19. Cad Saúde Pública. 2020;36(5):e00095220. https://doi.org/10.1590/0102-311x00095220

20. Food Security Information Network. Global Report on Food Crises: joint analysis for better decisions. FSIN; 2020. [citado 2020 jun 17]. Disponível em: https://www.fsinplatform.org/sites/default/files/resources/files/GRFC_2020_ ONLINE_200420_FINAL.pdf

21. Araújo FR, Calazans DLMS. Gestão das ações de segurança alimentar frente à pandemia pela COVID-19. Rev Adm Pública. 2020;54(4):1123-33. https://doi.org/10.1590/0034-761220200329 
22. Brown E, Das R, Brewer AG, Martinez E, Bilaver LA, Gupta RS. Food insecure and allergic in a pandemic: a vulnerable population. J Allergy Clin Immunol Pract. 2020;8(7):2149-51. https://doi.org/10.1016/j.jaip.2020.04.038

23. Recine E, Fagundes A, Silva BL, Garcia GS, Ribeiro RCL, Gabriel CG. Reflections on the National Council for Food and Nutrition Security and the confrontation of Covid-19 in Brazil. Rev Nutr. 2020;33:e200176. https://doi. org/10.1590/1678-9865202033e200176

24. Alpino TMA, Santos CRB, Barros DC, Freitas CM. COVID-19 e (in)segurança alimentar e nutricional: ações do Governo Federal brasileiro na pandemia frente aos desmontes orçamentários e institucionais. Cad Saúde Pública. 2020;36(8):e00161320. https://doi.org/10.1590/0102-311x00161320

25. Amorim ALB, Ribeiro Junior JRS, Bandoni DH. Programa Nacional de Alimentação Escolar: estratégias para enfrentar a insegurança alimentar durante e após a COVID-19. Rev Adm Pública. 2020;54(4):1134-45. https://doi. org/10.1590/0034-761220200349

26. Cardoso BB. A implementação do auxílio emergencial como medida excepcional de proteção social. Rev Adm Pública. 2020;54(4):1052-63. https://doi.org/10.1590/0034-761220200267

27. Isaac P. O mundo do trabalho e a pandemia de covid-19: um olhar sobre o setor informal. Cad Adm. 2020;28:66-70. https://doi.org/10.4025/cadadm.v28iEdição\%20E.53586.

28. Madeiro C. Governo corta 158 mil do Bolsa Família em meio a covid-19; 61\% são do NE. 20 mar 2020 [citado 11 jun 2020]. In: Portal Uol. Coronavírus. Macéio: Portal Uol; 2020. Disponível em: https://noticias.uol.com.br/politica/ ultimas-noticias/2020/03/20/governo-corta-158-mil-do-bolsa-familia-em-meio-ao-covid-19-61-sao-do-ne.htm

29. Ribeiro-Silva RC, Santos MP, Campello T, Aragão E, Guimarães JMM, Ferreira A, et al. Implicações da pandemia COVID-19 para a segurança alimentar e nutricional no Brasil. Ciênc Saúde Coletiva. 2020;25(9):3421-30. https:// doi.org/10.1590/1413-81232020259.22152020

30. CarvalhoSS. Os efeitos da pandemia sobreos rendimentos do trabalho e impacto do auxílio emergencial: o que dizem os microdados da PNAD covid-19. Brasília: Instituto de Pesquisa Econômica Aplicada; 2020 [citado 4 out 2020]. Disponível em: https://www.ipea.gov.br/portal/index.php?option=com_alphacontent\&view=alphacontent\&ltemid=369

31. Verdélio A. Governo vai criar programa de renda mínima após a pandemia, diz Guedes. 9 jun 2020. In: Agência Brasil. Brasília: Agência Brasil; 2020 [citado 17 jun 2020]. Disponível em: https://agenciabrasil.ebc.com.br/politica/ noticia/2020-06/governo-vai-criar-programa-de-renda-minima-apos-pandemia-diz-guedes

32. Paiva LH, Souza, PHGF, Bartholo L, Soares S. Evitando a pandemia da pobreza: possibilidades para o programa Bolsa Família e para o Cadastro Único em resposta à COVID-19. Rev Adm Pública. 2020;54(4):1097-110. https://doi. org/10.1590/0034-761220200243

33. Vasconcelos FAG, Machado ML, Medeiros MAT, Neves JA, Recine E, Pasquim EM. Public policies of food and nutrition in Brazil: From Lula to Temer. Rev Nutr. 2019;32:e180161. https://doi.org/10.1590/1678-9865201932e180161

34. Organización de las Naciones Unidas para la Alimentación y la Agricultura. El estado de la inseguridad alimentaria en el mundo: 2018. Roma: Organización; 2018 [citado 2020 jun 12]. Disponible en: http://www.fao.org/3/I9553ES/ i9553es.pdf

35. Hu Z. A new age of de structive austerity after the coronavirus. New York: The New Republic; 2020 [cited 2020 june 17]. Available from: https://newrepublic.com/article/157417/new-age-destructive-austerity-coronavirus

36. Instituto Brasileiro de Geografia e Estatística. Pesquisa de Orçamentos Familiares 2017-2018: análise da segurança alimentar no Brasil. Rio de Janeiro: Instituto; 2020 [citado 4 out 2020]. Disponível em: https://biblioteca.ibge.gov.br/ index.php/biblioteca-catalogo?view=detalhes\&id=2101749

37. Trovão CJBM. A pandemia da Covid-19 e a desigualdade de renda no Brasil: um olhar macrorregional para a proteção social e os auxílios emergenciais: texto para discussão. Natal: Universidade Federal do Rio Grande do Norte; 2020 [citado 11 jun 2020]. Disponível em: https://ccsa.ufrn.br/portal/wp-content/uploads/2020/05/TROV\%C3\%8302020-PANDEMIA-E-DESIGUeALDADE.pdf

38. Organización de Las Naciones Unidas. COVID-19: políticas econômicas e sociais no Brasil colocam milhões de vidas em risco. Chile: ONU para los Derechos Humanos; 2020 [citado 17 jun 2020]. Disponível em: https://acnudh.org/ pt-br/covid-19-politicas-economicas-y-sociales-en-brasil-ponen-en-riesgo-millones-de-vidas-expertos-onu/

39. The Lancet. COVID-19 in Brazil: "Sowhat? Lancet. 2020;395(10235):1461. https://doi.org/10.1016/S0140-6736(20)31095-3 